10. Traverse T. (2017).'Music as a Psychological Factor of Influence on the Person' Instytut psykholohii im. H. S. Kostiuka APN Ukrainy, Kyiv [H. Kostiuk Institute of Psychology, Academy of Pedagogical Sciences of Ukraine], [online] Available at: 〈http://newacropolis.org.ua/ru/node/12627> [Accessed 23 November 2017].

(C) Іванов О. К., 2018

УДК 78.071.1:929

\author{
Іванова Валентина Леонідівна \\ кандидат педагогічних наук, \\ Відокремлений підрозділ «Миколаївська філія \\ Київського національного університету \\ культури і мистецтв» \\ Миколаїв, Украӥна \\ ivanovavalleon@gmail.com
}

\title{
КОМПОЗИТОР ЄВГЕН МАГАЛІФ: БІОГРАФІЧНИЙ І ТВОРЧИЙ ЕКСКУРС
}

Мета статті: вивчення творчого доробку композитора Євгена Магаліфа та репрезентація його музичній спільноті України. Методи і завдання дослідження: аналіз наукових джерел про особливості композиторської творчості; вивчення доступних матеріалів про життя і творчість С. Магаліфа; огляд його музичних творів з позицій доцільності їх використання в концертній і педагогічній діяльності; узагальнення світового музичного досвіду виконання творів для духових інструментів $€$. Магаліфа. Наукова новизна: вперше досліджено стилістичні й жанрові пріоритети творчості композитора $€$. Магаліфа, а також здійснено оцінку мистецької цінності його композицій. Висновки. Дослідженням встановлено, що композиції Євгена Магаліфа мають художню цінність, здобули визнання виконавців і шанувальників музики. Його твори є досконалим втіленням традицій сучасної класики та гідні бути представленими в концертній $\mathrm{i}$ педагогічній діяльності. Перспективи подальших досліджень ми вбачаємо як у подальшому вивченні стилістичних i жанрових засад творчості $€$. Магаліфа, так i в розвідці нових імен композиторів близького й далекого зарубіжжя.

Ключові слова: композитор Євген Магаліф, композиторська творчість, мистецька спадщина, творчий доробок, музичний твір, музична комунікація, стиль і жанр

Иванова Валентина Леонидовна, кандидат педагогических наук, Обособленное подразделение «Николаевский филиал Киевского Национального университета культуры и искусств, Николаев, Украина 


\section{Композитор Евгений Магалиф: биографический и творческий экскурс}

Цель статьи: изучение творческого наследия композитора Евгения Магалифа и репрезентация его музыкальному сообществу Украины. Методы и задания исследования: анализ научных источников об особенностях композиторского творчества; изучение доступных материалов о жизни и творчестве Е. Магалифа; обзор его музыкальных произведений с позиций целесообразности их использования в концертной и педагогической деятельности; обобщение мирового музыкального опыта исполнения произведений для духовых инструментов Е. Магалифа. Научная новизна: впервые исследованы стилистические и жанровые приоритеты творчества композитора Е. Магалифа и осуществлена оценка художественной ценности его композиций. Выводы. Исследованием установлено, что композиции Евгения Магалифа имеют художественную ценность, снискали признание исполнителей и почитателей музыки. Его композиции являются совершенным воплощением традиций современной классики и достойны использоваться в концертной и педагогической деятельности. Перспективы дальнейших исследований мы видим как в изучении стилистических и жанровых принципов творчества Е. Магалифа, так и в разведке новых имен композиторов ближнего и дальнего зарубежья.

Ключевые слова: композитор Евгений Магалиф, композиторское творчество, художественное наследие, творческое наследие, музыкальное произведение, музыкальная коммуникация, стиль и жанр

Ivanova Valentyna, PhD in Pedagogical Sciences, Associate Professor, Separate subdivision "Mykolaiv branch of Kyiv National University of Culture and Arts»

Composer Eugene Magalif: a biographical and creative excursus

The purpose of the article is to study the creative heritage of the composer Eugene Magalif and his representation to the Ukrainian musical community. Methodology and tasks of the research is to analyse scientific sources about the composer's creativity peculiarities; to study available materials about E. Magalif's life and work; to review his musical works from the standpoint of their use appropriateness in a concert and pedagogical activity; to generalise the world musical experience of E. Magalif's wind instruments works performance. Scientific novelty: for the first time the composer E. Magalif's stylistic and genre priorities of creativity were investigated and the artistic value of his compositions was assessed. Conclusions. The study found out that the compositions of Eugene Magalif have artistic value, having won the recognition of music performers and admirers. His compositions are the perfect embodiment of the modern classics traditions and deserve to be used in concert and pedagogical activity. Prospects for further research are to study E. Magalif's creativity stylistic and genre principles, as well as to explore new names of composers from near and far abroad countries.

Key words: composer Eugene Magalif, composer creativity, artistic heritage, creative heritage, musical composition, musical communication, style and genre. 
Вступ. У наш час, коли стали можливими музичні комунікативні зв'язки в світовому масштабі, розпочався активний процес збагачення музичної свідомості недоступними раніше музичними творами найрізноманітніших стилів i жанрів. Розширюється коло композиторів, чиї творчі здобутки заслуговують на увагу i визнання, з'являються все більше досліджень мистецької спадщини композиторів «нової хвилі» і оцінки художньої цінності творчого доробку.

Для музичної спільноти України залишається маловідомою творчість композитора Євгена Магаліфа (США). Але в країнах Європи та США його твори вже отримали визнання виконавців та слухачів i все частіше використовуються в концертній i педагогічній діяльності. Для нас буде корисним досвід композитора, якій спромігся утвердитись у музичному світі завдяки своїй наполегливості й творчій активності. Зараз С. Магаліф викладає курс музики в старших класах школи м. Трентон, столиці штату Нью-Джерсі, керує хором, грає на органі в церкві. Він став членом ASCAP (Американського Товариства композиторів, авторів і видавців) і Асоціації викладачів штату НьюДжерсі.

У цій статті ми прагнемо здійснити біографічну реконструкцію творчої постаті Є. Магаліфа i ознайомити музичну спільноту України з його композиторським доробком. Звернення до біографії митця допоможе глибше зрозуміти ідеї та цінності музичних творів Є. Магаліфа, адже на формування творчої особистості музиканта безпосередньо впливають його талант, виховання, музичне оточення.

Відомий мистецтвознавець О. Кривцун пропонує оригінальне пояснення такого зв'язку: «...життєвий шлях i творчий шлях митця - це сполучені посудини, в самій природі таланту закладена приреченість до виняткової долі» [2, с. 162].

Досліджуючи творчий доробок композитора Є. Магаліфа, ми вважаємо доцільним не тільки здійснити загальний аналіз його багатожанрової творчості, а й акцентувати увагу на його плідній діяльності як автора композицій для духових інструментів, що $\epsilon$ явищем не поширеним в композиторській діяльності.

Аналіз публікацій. Значення постаті митця в контексті світоглядних характеристик епохи й культурної ситуації теоретично осмислені 3 позицій філософії (Ж.-П. Сартр, А. Камю, Е. Фромм, Ш. Муньє, М. Каган та ін.). Психологічні аспекти творчої діяльності, специфіки функцій мистецтва, морально-естетичних позицій митця висвітлені в працях із загальних проблем психології (Б. Г. Ананьєв, О. О. Бодалєв, О. М. Леонтьєв, В. П. Тугарінов).

У дослідженнях українських науковців аналізується феномен особистості композитора, митця, що репрезентує культурну епоху (Л. Архимович, С. Белза, О. Завальнюк, С. Лісецький, Л. Кияновська, В. Рожок, О. Берегова, М. Гордійчук, Д. Ревуцький та ін.).

У цих дослідженнях значна увага приділяється розкриттю особистості композитора, стильових і жанрових чинників музичної творчості, здійснено спробу осягнути параметри композиторських пошуків і звершень. 
У наукових джерелах ми прагнули знайти підтвердження гіпотези про те, що:

- $\quad$ для композитора є природнім прагнення до творчої самореалізації в різних музичних жанрах. Творчі пріоритети можуть змінюватись під впливом оновленого світосприйняття, творчого пошуку, набутого досвіду і життєвих обставин;

- музика композитора $\epsilon$ прямим відображенням його емоційних станів і духовної гармонії з оточуючим світом;

- запорукою публічного успіху композитора є широкі музичнокомунікативні зв'язки i творча дружба 3 диригентами, виконавцями, продюсерами тощо.

Так, В. Медушевський переконаний, що сприйняття музичного твору слухачем «залежить від уміння автора враховувати закони сприйняття, співвідносити їх з умовами й цілями музичного спілкування» [6].

Л. Т. Левчук наголошує на об'єктивно-суб'єктивному характері мистецтва. Зокрема, зазначається, що пізнаючи об’єктивну дійсність, митець відбирає ті ії сторони і прояви, які найсильніше розкривають його власний внутрішній світ, світогляд, смаки, мистецьку позицію [3, с. 127].

У контексті дослідження нами опрацьовані публіцистичні матеріали, рецензії і відгуки про творчість Є. Магаліфа, а також особисті нотатки композитора.

Мета статті - вивчення творчості композитора Євгена Магаліфа і представлення його музичній спільноті України.

Методологія і завдання дослідження: аналіз наукових джерел про особливості композиторської творчості; вивчення доступних матеріалів про життя i творчість $€$. Магаліфа; огляд його музичних творів 3 позицій доцільності їх використання в концертній i педагогічній діяльності; узагальнення світового музичного досвіду виконання творів для духових інструментів $€$. Магаліфа.

Виклад основного матеріалу. Євген Магаліф народився в місті Вітебську (Білорусь), закінчив Вітебський музичний коледж та Білоруську академію музики. У Білорусії він став відомим завдяки своїм пісням і музиці для дітей. Є. Магаліф - автор мюзиклу «Свинопас», кантати «Бармалей», музики для театру, радіо й ТБ, інструментальних творів, Християнської хорової музики і популярних пісень та балад. У 1992 р. разом з популярним виконавцем Данчиком (Богдан Андрусишин) він записав добре відомий білоруським меломанам альбом «Мы ещё встретимся»-«Мы яшчэ сустрэнемся».

Першим твором Є. Магаліфа, що потрапив до фондів Всесоюзного радіо, стала пісня «Грав рояль» (вірші автора). Пісня отримала високу оцінку композитора Т.Хреннікова та поета М. Матусовського. Записав іiі заслужений артист Росії Леонід Серебренніков з Великим естрадно-симфонічним оркестром Всесоюзного радіо і ТБ.

У другій пол. 1980-х рр. пісні Свгена Магаліфа часто звучали в радіоі телепередачах («Прем’єра пісні» і «Зустрінемося після одинадцяти»), посідали високі місця в хіт-парадах. На фестивалі «Слов'янський Базар» були 
представлені пісні Є. Магаліфа «Свята» (вірші А. Давидової) у виконанні гурту «Ветразь» 3 хором хлопчиків і пісня «Не исчезай» на вірші $С$. Свтушенко у виконанні Народного артиста Білорусії Н. Скорикова. У 2008 і 2010 роках Є. Магаліф був почесним гостем Міжнародного фестивалю «Слов’янський Базар» у Вітебську.

У 2009 р. в Польщі з великим успіхом пройшла прем'єра композиції Є. Магаліфа Fairy Tale («Казка») у виконанні симфонічного оркестру Нижньої Сілезії, а хоровою капелою м. Гродно були записані духовні хори «У Царстві Твоїм», «Херувимська» і «Отче Наш». У листі до композитора Ректор Мінської духовної академії i семінарії архімандрит Йосаф i регент протоієрей А. Скробота висловили шану його творчості: «Ваші твори, шановний Свгене Борисовичу, без сумніву, нове слово в церковному православному світі» [4].

Свген Магаліф пригадує такий епізод 3 творчого життя: «Цікава доля у моєї кантати для дітей «Бармалей» на вірші К. Чуковського. Писав я ії ще під час навчання в консерваторії «під тиском» диригента спеціалізованої музичної школи при консерваторії Алли Мазурової. Минув час і я зовсім забув про «Бармалея», а ноти взагалі загубив. Майже через сорок років, будучи гостями фестивалю «Слов’янський базар», ми з дружиною поїхали в Гродно, де хорова капела співала мою духовну музику. Для мене стало цілковитим сюрпризом, коли у фіналі концерту прозвучала кантата «Бармалей». Я був збентежений і розчулений до сліз. Виявилось, що і в рідному Вітебську міський молодіжний хор також їі співає. Я поновив ноти, зробив нову редакцію для хору і оркестру.

Тепер кантату «Бармалей» співають у багатьох містах Росії і Белорусії, а нещодавно відбулася прем'єра в Дагестані (!). Дивовижно» [1].

У 2016 р. в міжнародному продажу з'явився диск Євгена Магаліфа з його композиціями в класичному стилі «Колібрі», який значно розширив коло шанувальників його творчості. Стиль його музики можна визначити як комбінацію класичної й популярної, або назвати - «сучасна класика».

31990 р. композитор мешкає в США. У непростих життєвих обставинах Є. Магаліф зумів адаптуватися до нових реалій і здобути визнання в США, Росії, Німеччини, Польщі, Франції, Білорусії, Чеській Республіці, Фінляндії, Литві, Болгарії, Ізраїлі.

Характеризуючи широку різножанровість композиторської творчості Свгена Магаліфа, ми акцентуємо увагу на його плідній роботі в жанрі інструментальної музики для духових інструментів.

Ключовим поняттям для розуміння глибини музичного мислення композитора є жанр інструментальної музики, який має цілий спектр визначень. Зокрема такі: «категорія художнього мислення, що оптимально реалізується за посередництвом музичних інструментів шляхом забезпечення трансформації їх іманентних властивостей відповідно до естетичних запитів часу» $[8$, с. 5].

Одним 3 найбільш улюблених музикантами i публікою творів Є. Магаліфа $\epsilon$ «Колібрі» для флейти i струнного оркестру, який $з$ успіхом виконувався в різних країнах відомими оркестрами та диригентами. 
Композиція «Колібрі» була створена в 2009 р. на прохання знаних флейтистів Едуарда і Олега Ситянко. Сьогодні цей твір широко відомий в різних ансамблевих варіантах і часто виконується і видається в Європі та США. Цю маленьку пташку композитор вважає своїм щасливим талісманом.

Ось як пригадує історію створення цієї п’єси сам автор: «Одного разу, в розмові по телефону, мій друг, флейтист з Фінляндії (Ситянко), запропонував написати мені твір для флейти і оркестру. У цей момент до мене на балкон прилетіли колібрі, і легкі, швидкі рухи цієї маленької пташки відразу викликали у мене асоціації зі звучанням і можливостями флейти, флейти-пікколо. Так з'явився твір «Колібрі», створений спочатку для флейти і струнного оркестру, потім для флейти або пікколо, як сольного інструмента 3 різного роду ансамблями» [4].

Програмна установка, що закладена в назві твору - «Колібрі», допомогла композитору створити яскраву музичну мініатюру, яка якнайкраще підходить для виконання на флейті, а головне, засвідчила майстерність композитора. Видавництва Англії і США уклали з Свгеном Магаліфом авторські угоди про довгострокове співробітництво з видання його композицій.

Знаковою для Є. Магаліфа стала зустріч з прекрасним флейтистом, сером Джеймсом Голуеєм (James Galway), яка надалі переросла в міцну творчу дружбу. Дж. Голуей - це флейтист номер один у світі. Він запросив Євгена Магаліфа на свій фестиваль в Швейцарії і сприяв у виданні його творів у видавництві, з яким він співпрацює. Тобто, він рекомендує музику - ставить, так би мовити, своє imprimatur (відмітка «в друк»- belisrael. info).

Зараз видавництво оперативно готує до друку декілька творів для флейти Євгена Магаліфа, щоб представити їх на загальній конвенції флейтистів США в серпні 2018 р., де ці твори будуть вперше виконуватись, а композитор буде представлений як новий автор видавництва.

Багато років співпраці пов'язують композитора Є. Магаліфа 3 флейтовим Оркестром Chesapeake Flute Consort, який був заснований професійною флейтисткою Гейл Весладж в 1997 p. Вона закінчила державний університет в Сан-Дієго і має ступінь магістра по класу флейти. Гейл Весладж була головним флейтистом i солістом Гавайської філармонії і Гавайського камерного оркестру, оперного оркестру в Сан-Дієго, симфонічного оркестру Санта-Крус і камерного оркестру в Кармелі, штат Каліфорнія.

На даний час Гейл регулярно виступає в Балтіморі й Вашингтоні з різними камерними оркестрами. Також вона керує своїми Chesapeake Flute Consort оркестром і юнацьким Chesapeake Youth Symphony Orchestra, з якими успішно гастролює світом. Творча дружба $€$. Магаліфа з оркестром Chesapeake Flute Consort розпочалася 3 виконання оркестром обробки $€$. Магаліфа українського «Щедрика», відомого в США як «Carol of the Bells». Диригент оркестру Chesapeake Flute Consort Гейл Весладж несподівано повідомила композитору, що оркестр двічі «на біс» виконав «Щедрика» в Білому домі. Згодом репертуар оркестру поповнився новими творами С. Магаліфа, які виконуються з незмінним успіхом. 
У 2017 р. оркестр Chesapeake Flute Consort надіслав відео виконання двох творів С. Магаліфа на конкурсний відбір для виступу на Конвенції флейтистів США. На участь у концертах Конвенції претендували 500 оркестрів 3 різних країн, але саме Chesapeake Flute Consort був у списку серед восьми відібраних і готується виконувати музику Свгена Магаліфа.

16 лютого 2018 p. в Російському Культурному Центрі (РКЦ) у Вашингтоні відбувся творчий вечір композитора Євгена Магаліфа. У програмі вечора звучали твори композитора, написані ним спеціально для флейтового Оркестру Chesapeake Flute Consort, серед яких і візитна картка композитора всесвітньо відоме «Колібрі», найяскравіший твір для флейти.

Перенести глядачів у швейцарські Альпи Свгену Магаліф вдалося завдяки виконанню прекрасної музики, написаної на замовлення Фестивалю в Швейцарії. Прем’єра п’єси «Лебеді на альпійському озері», навіяної природою Альп, успішно пройшла в одному з театрів Женеви, а в США цей твір відмінно зіграв на концерті в РКЦ Chesapeake Flute Consort.

Варіації на тему фінської «Польки Єви» Євген Магаліф написав в 2016 р. У ній, поряд 3 флейтами, він використовував гру на пляшках. Цікавий ефект відбувається, коли виконавець дме в пляшку, наповнену водою, i, в залежності від наповнюваності, звучить певна нота. Таким чином, музиканти показали свою майстерність, граючи на пивних і лимонадних пляшках разом з іншими флейтистами. Це було дуже оригінально і справило на глядачів велике враження.

Всі твори С. Магаліфа дуже різноманітні за жанрами і стилістикою. Так, напівтоновий регтайм «Пінгвін» зацікавив такою композиторською новацією, в його мелодії немає ніяких інших інтервалів, а тільки півтони. Це один із безлічі композиторських прийомів маестро, якими він володіє досконало, збагачуючи музичну мову. Композицію «Пінгвін» оркестр Chesapeake Flute Consort замовив композитору спеціально для свого репертуару.

Євген Магаліф пише не тільки інструментальну музику для окремих виконавців і оркестрів, але продовжує плідно працювати в жанрі вокальної музика. Це мелодійні, досконалі й популярні пісні та романси. На авторському концерті у Вашингтоні композитор особисто виконав кілька своїх пісень, написаних у різні роки. Першою прозвучала пісня «Грав Рояль», яку свого часу виконував і записував радянський та російський співак Леонід Серебренніков з Великим Естрадно-Симфонічним Оркестром Радіо.

У РКЦ також прозвучала пісня «Квіти Росії», яку композитор написав на слова білоруського поета М. Гвоздікова і пісня «Не исчезай» на вірші $€$. Свтушенка. Свого часу iï вперше виконав народний артист Білорусі Микола Скориков і Євгену Євтушенко дуже сподобалася музика Є. Магаліфа на цей сильний і непростий для розуміння вірш. Він навіть розцілував талановитого композитора, і був дуже зворушений і задоволений тим, як вона прозвучала.

Є. Магаліфа пов'язують міцні творчі стосунки з добре відомою в США російсько-американською співачкою Вікторією Сухарєвою. Вікторія та іiі чоловік баяніст Артем Старченко давно товаришують 3 композитором, 
і Вікторія вже встигла записати кілька його прекрасних романсів. Серед них відзначимо «Я не прошу благословенья» на вірші А. Вербик.

Творчий вечір Є. Магаліфа вийшов дуже цікавим i незвичайним. Насамперед тим, що знайомство 3 творчістю композитора розпочалося з виконання його музики таким рідкісним і незвичайним оркестром флейт. Глядачі вперше познайомилися з оркестром Chesapeake Flute Consort i вперше побачили таке розмаїття флейт - це флейта-пікколо, концертні С-флейти (найпоширеніша флейта), альтові флейти, басові й контрабасові флейти. Усі разом вони створюють повноцінне звучання цілого оркестру. В оркестрі близько 20 музикантів, серед яких є і професіонали, і аматори, і студенти. За час свого існування Chesapeake Flute Consort оркестр багато виступав як в Америці, так і за кордоном - у Франції, Бельгії та інших країнах світу і завжди виконує твори С. Магаліфа, найбільшим успіхом користується виконання українського «Щедрика».

Музика Є. Магаліфа дуже підходить до стилістики цього оркестру і він продовжує співпрацювати з ним. Маестро Юрій Темірканов писав, що «музика Свгена Магаліфа чудова, насамперед своїм професіоналізмом, а також цікава і дотепна» [5]. Досліджуючи творчість Є. Магаліфа, ми повністю підтверджуємо слова знаменитого диригента.

У квітні 2017 р.відбулася цікава музична подія в французькому Ліоні 60 флейтистів з усього світу виконували музику Є. Магаліфа на честь його 60 річчя. Такий знак поваги підкреслює рівень визнання творчості композитора.

У травні 2017 р. в сибірському місті Чита з ініціативи місцевої музичної громади відбувся концерт музики С. Магаліфа Композитор спілкувався з виконавцями і глядачами в режимі відео конференції і був вражений теплотою спілкування.

Ще один концерт, присвячений 60-річчю Є. Магаліфа, відбувся в Україні - 28 жовтня 2017 р. в філармонії міста Дніпро (колишній Дніпропетровськ). Звучала симфонічна і камерна музика, хорові й інструментальні твори. У концерті взяли участь друзі С. Магаліфа, флейтисти з Фінляндії та Польщі брати Ситянко, які виконали нові твори Є. Магаліфа. Також уперше прозвучали п’ять танців 3 мюзиклу «Дике полювання короля Стаха», який композитор написав для Мінського музичного театру. Цікавою була прем'єра пісні «Симфонія дощу», яку Свген Магаліф створив на вірші Олександра Іванова, професора Миколаївської філії КНУКіМ і репрезентував глядачам в авторському виконанні.

Наведемо, як приклад, наш досвід творчої співпраці 3 композитором Євгеном Магаліфом. Нас зацікавили його музичні твори для духових інструментів. Через інформаційні мережі Інтернету ми встановили контакт з композитором і отримали дозвіл на виконання його творів.

Наша співтворчість базувалася на спільній зацікавленості: 3 боку композитора - почути свої музичні твори в новій інтерпретації та уточнити особистісну концепцію твору, 3 нашого боку - отримати до репертуару музичний твір сучасного композитора і бути одним із перших його виконавців. 
Так, Свген Магаліф запропонував нам виконати твір «Мазурка» для дуету флейт і фортепіано. Цей твір ми виконали в іншому інструментальному складі флейта, скрипка і фортепіано. Відеозапис виконання твору ми надіслали автору для схвалення. Композитор гідно оцінив нашу роботу і був здивований нашою інструментальною інтерпретацією. Особливо важливим було знайти правильні співвідношення між нотним текстом і реальним тембральним його звучанням. На цьому прикладі ми продемонстрували як в залежності від інтерпретації виконавця змінюється реальне звучання написаної автором музики. Про цей процес американський музикознавець Альфред Джон Гудрих висловився так: «...Ми читаємо ноти, а слухаємо звуки» $[9$, с. 26].

У співпраці з композитором, ми намагалися пізнати сутність питання: що є головним змістом музики - нотний текст чи його звучання, яке існує тільки в процесі виконання? Нотована музика складає скелет музичної думки композитора, яка не повністю відтворює логіку композиції й тому відкриває широкі можливості для інтерпретації. Композитор намагається дати більш детальне словесне позначення музичної думки (наприклад, con amabilita, dolce, furioso, energico, con brio, mesto). Але виконання - дає життя музичній думці, привносить різноманітні зміни динаміки, темпу, тембру. Виконавець намагається знайти більш переконливу форму музичного втілення характеру твору, його емоційного настрою.

Г. М. Падалка наводить такий приклад: «Композитор, художник, поет пише не в простір, не тільки самовиражається, не тільки прагне передати певну інформацію, а й чекає співчуття, оцінки. Л. Бетховен виливає свою тугу, біль за втраченим коханням, коли пише «Місячну» сонату. Це дійсно так. Але при цьому він підсвідомо сподівається, що хтось поділятиме його переживання, що хтось зможе перейнятись його відчаєм, що невідомий слухач буде співчувати його горю» [7, с. 19].

Так, твір Євгена Магаліфа «NIÑO LINDO», який був написаний для флейти 3 фортепіано, автор запропонував адаптувати для іншого музичного інструменту - альтового саксофона. Тембральне забарвлення саксофона надало цьому музичному твору нову енергетику й художню значимість. Свого часу Беннетт Реймер висловив таку думку, що «природа і цінність музичного виховання визначена не природою і цінністю музики, а виключно музичною практикою» $[10$, с. 233$]$.

У тісній співтворчості з композитором $Є$. Магаліфом була створена ще одна цікава робота. Композитор присвятив музичний твір своїй дружині Тетяні i назвав на іiі честь «Для Тетяни». Твір він написав для незвичного інструментального складу - флейта, саксофон-альт, фортепіано. Ця композиція була вперше виконана нашим інструментальним ансамблем, студентами Миколаївської філії «КНУКіМ» - Курченко Катерина (флейта), Волченкова Катерина (саксофон), Боровицька Олена (фортепіано). Наша робота була високо оцінена автором твору і виставлена на сайті композитора. На черзі нова робота: інтерпретувати твір Євгена Магаліфа «Соловей і троянда» для флейти та інструментального тріо (дві гітари і контрабас). 
Наш колектив і композитор Євген Магаліф дуже цінуємо нашу творчу співпрацю. I дивовижно, що знаходячись так далеко один від одного - США і Україна - ми сповідуємо єдині принципи музичного виконання в найрізноманітних формах. Ми вважаємо, що не існує виконання абсолютно «вірного», яке буде влаштовувати смаки і традиції всіх людей без винятку, а тільки творчий пошук $є$ важливою складовою процесу музичного виконання.

Наше дослідження не претендує на всеосяжність, але грунтується на конкретних дослідженнях і прикладах, які можуть заохотити до роздумів про професійні та кар'єрні можливості творчої особистості. Композитор Свген Магаліф вважає, що головною умовою успішної музичної діяльності $€$ наполегливість у досягненні мети і відданість служінню музиці.

Наукова новизна: вперше досліджено стилістичні й жанрові пріоритети творчості композитора $Є$. Магаліфа та здійснено оцінку мистецької цінності його композицій.

Висновки. Дослідженням встановлено, що композиторський доробок Євгена Магаліфа має художню цінність, здобув визнання виконавців і шанувальників музики. Його композиції є досконалим втіленням традицій сучасної класики і гідні бути представленими в концертній та педагогічній діяльності. Перспективи подальших досліджень ми вбачаємо як у поглибленому вивченні стилістичних і жанрових засад творчості $Є$. Магаліфа, так і в розвідці нових імен композиторів близького й далекого зарубіжжя.

\section{Список використаних джерел}

1. Кошевая, А. (2016). «Евгений Магалиф - Браво, маэстро!» : [Електронный ресурс]. - Режим доступа: https://www.gorozhanka.com/singlepost/.../Евгений-Магалиф-БРАВО-МАЭСТРО. - Загл. с экрана. - Дата обращения 20.04.2016.

2. Кривцун О. А. Психология искусства / О. А. Кривцун. - Москва : Издво Литературного ин-та им. А. М. Горького, 2000. -224 с.

3. Левчук Л. У творчій лабораторії митця / Л. Левчук. - Київ : Мистецтво, 1978. - 133с.

4. Криченко О. (2018), «Концерт композитора Евгения Магалифа и оркестра Chesapeake Flute Consort в РКЦ» : [Електронный ресурс]. - Режим доступа: www.russianwashingtonbaltimore.com/.../koncert-kompozitora-evgeniyamagalifa-i- о. - Загл. с экрана. - Дата обращения 22.02.2018.

5. Максимюк Я. (2017). «Евгений Магалиф: в США я достиг того, о чем и не мечтал // Беседа к юбилею Евгения Магалифа» : [Електронный ресурс]. Режим доступа: available at: belisrael.info/?p=11258. - Загл. с экрана. - Дата обращения 20.11.2017.

6. Медушевский В. В. О закономерностях и средствах художественного воздействия музыки / В. В. Медушевский. - Москва : Музыка, 1976. - 253 с.

7. Падалка Г. М. Педагогіка мистецтва. Теорія і методика викладання мистецьких дисциплін / Г. М. Падалка. - Київ : Освіта України, 2008. - 274 с.

8. Пославський А. О. Специфіка струнно-смичкового інструменталізму у камерних ансамблях композиторів Нової віденської школи : дис. ... канд. 
мистецтвознавства: спец. 17.00.03 «Музичне мистецтво» / А. О. Пославський. Львів, 2014. - 230 с.

9. Goodrich A. J. Complete Musical Analysis / A. J. Goodrich. - Chicago: Root \& Sons Music, 1889. - 352 p.

10. Reimer B. Can we understand music of foreign cultures? / B. Reimer // Proceeding of the 21st World Conference on the International Society of Music Education. - Florida, USA, 1994. - Vol. 31. - pp. 227-245.

\section{References}

1. Koshevaya, A. (2016). Evgenii Magalif - Bravo, maestro!, Available at: <https://www.gorozhanka.com/single-post/.../ Eugene-Magalif-BRAVO-MAESTRO>. [Accessed 20 April 2016]. Title from the screen.

2. Krivtsun, O.A. (2000). Psychology of Art. Moscow: Maxim Gorky Literature Institute Publishing House.

3. Levchuk, L. (1978). In the creative laboratory of the artist. Kyiv: Mystetstvo.

4. Krichenko, O. (2018,). Concert of composer Eugene Magalif and Chesapeake Flute Consort in RCH. Available at: <www.russian Washington baltimore.com/.../koncert-kompozitora-evgeniya-magalifa-i-o>. [Accessed 22 February 2016]. Title from the screen.

5. Maksimyuk, Ya. (2017). Eugene Magalif: in the United States I achieved what I have never dreamed about. V: A cconversation to the jubilee of Eugene Magalif, Available at: <belisrael.info/?p=11258>. [Accessed 20 November 2017]. Title from the screen.

6. Medushevskiy, V.V. (1976). On the regularities and means of artistic influence of music. Moscow : Muzyka.

7. Padalka, G.M. (2008). Art Pedagogy. Theory and methodology of teaching artistic disciplines. Kyiv: Osvita Ukrainy.

8. Poslavskiy, A.O. (2014). Specifics of string instrumentalism in chamber ensembles of the New Viennese School composers. D.Ed. Lviv.

9. Goodrich, A.J. (1989). Complete Musical Analysis. Chicago: Root \& Sons Music.

10. Reimer, B. (1994). Can we understand music of foreign cultures? Proceeding of the 21st World Conference on the International Society of Music Education. Florida, USA.

(C) Іванова В. Л., 2017 